\title{
Uses of information resources: An analytical study of library services of MNV university
}

\author{
Subhash Chand \\ Librarian Advanced Educational Institutions, Palwal, Haryana Jiwaji University, Gwalior, Madhya Pradesh, India \\ *Corresponding Author: Subhash Chand \\ Email: subhash_aitm@yahoo.co.in
}

\begin{abstract}
The Institution which provides higher education is University. The university library plays major roles to full-fill their objectives. As we know a university library contains print and electronic information resources. Students, Researchers and Teachers come together on same platform and getting their required information. Today it has been seen that users required print as well as electronic infor mation. So there is a new way opened for library science researchers how libraries are maintain their information resources. How libraries manage electronic resources for the purpose of better utilization. In this paper I try to analyses the uses pattern and management of e-resources of $\mathrm{M} \mathrm{V} \mathrm{N}$ University Library, Palwal, Haryana State.
\end{abstract}

Keywords: ICT, CD-ROM, OPAC.

\section{Introduction}

There are Varieties of institution involved in higher education activities in different field of knowledge in the nation. In the opening library was a stockroom of books and other reading materials and librarian was a custodian only. The relevance of ICT in information dispensation many products and services comes in existence. The application of new technologies in libraries, technology changes the face of libraries. Major changes have been seen in the style and services of libraries. The libraries modified their structure and resources, services, and mode of services.

\section{Literature review}

Shelburne ${ }^{37}$, Wendy Allen (2009) investigated through a major survey the usage patterns and library patron attitudes toward e-books. The study explores a university community's invention and understanding of e-books, their likes and dislikes about book content in electronic format as against print, and their forecast of how they will utilize electronic and print book materials in times to come. The study finds overwhelming response with respect to acceptance of e-books and reveals the fact they have become inevitable part of library service. The results, based on a study conducted in alliance with Springer, explore ebook awareness and attitudes into faculty, graduate student and undergraduate student constituent groups. Additionally, statistics are added to accompaniment the survey results by reflecting that the usage of e-book content at the University of Illinois is rising at a brisk rate.

Helsinki University of Technology Library (2010) in alliance with the strategic usability research group, various e-book readers was studied and evaluated by both professionals and students. As part of the research, e-book readers were assigned to students for a single tenure of study with all the course matter as digital collection. Students gathered the review comments through discussions, study diaries and questionnaires. In the next part of the research the e-book readers were analyzed to address the issues like what demands and restrictions they pose on digital stuff in the library and the extent of the usefulness of library's present e-resources in compatibility with available devices. It was found that the compatibility was questionable with many licensed e-materials, whereas most open access stuff is available for free download and access and retrieval.

Vasanthi, J. and S. Ravi (2010) discussed the impact of $\mathrm{e}-$ resources and user perceptions in professional education. Authors say that the librarians are forced to develop library portal and motivate the user community to move from print to electronic version which leads quik access to required information and to provide services.

Sathiyamurthi, M. G. and M. Arvinthan (2010) suggested that in the past information was in the form of printed material, palm leafs etc. After introduction of ICT in libraries, the existing and new information will be provided to the users in the form of electronically i.e. e - resources.

\section{Objective of the study}

Some main objectives of the present study are:

1. To examine current situation of e-resources in $\mathrm{M} \mathrm{V} \mathrm{N}$ University Library of Palwal.

2. To know about selection policy adopting by MVN university Library.

3. To know about worth, changing approach, and services effectiveness of $\mathrm{M} \mathrm{VN}$ University library in the viewpoint of e-resources.

4. To trace the weaknesses and to suggest the traditions to get better the lacunas.

\section{Scope of the study}

There are 41 universities in Haryana. A number of university working in city and some of in rural areas. $\mathrm{M} \mathrm{V}$ $\mathrm{N}$ University is situated on NH-2, Delhi-Mathura Road conducting UG, PG and Ph.D. courses. 


\section{Diagram 1: M V N University}

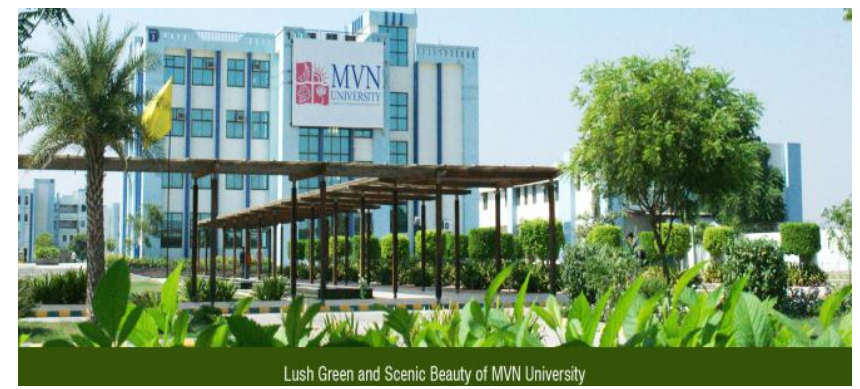

The MVN University Library fighting fit operational with

\begin{tabular}{|c|c|}
\hline Books & 65000 \\
\hline News papers & 14 \\
\hline Journals & 65 \\
\hline Online Journals & 36 \\
\hline
\end{tabular}

\section{Research Methodologies:}

For this study a questionnaire has been prepared and distributed to the user's custody in outlook of various issue and queries linked with both the types of information resources and their uses. In present study a survey method of research adopted. 100 questionnaires were distributed in the university library and in the campus to the all types of respondents included students, researchers staff members etc. Basically data collected through questionnaires and a statistical analysis was made on the applications of various statistical techniques i.e. Tables, Charts, diagrams etc.

Data analysis and interpretation: The study conduct via questionnaires distributed for my part in library and university campus and collected personally.

Table 1: Library stock

\begin{tabular}{|c|c|c|c|c|c|c|c|c|}
\hline & $\begin{array}{c}\text { Library } \\
\text { stock }\end{array}$ & \multicolumn{2}{|c|}{ Text books } & \multicolumn{2}{|c|}{$\begin{array}{c}\text { Ref. } \\
\text { Collection }\end{array}$} & \multicolumn{2}{c|}{$\begin{array}{c}\text { Other } \\
\text { (Thesis, } \\
\text { Reports) }\end{array}$} & $\begin{array}{c}\text { Per. } \\
\text { (Total) }\end{array}$ \\
\hline & No. & No. & $\%$ & No. & $\%$ & No. & $\%$ & \\
\hline M V N University, Palwal, Haryana & 65000 & 56500 & 86.92 & 7000 & 10.76 & 1500 & 2.32 & $100 \%$ \\
\hline
\end{tabular}

Diagram 1: Library stock of MVN university library

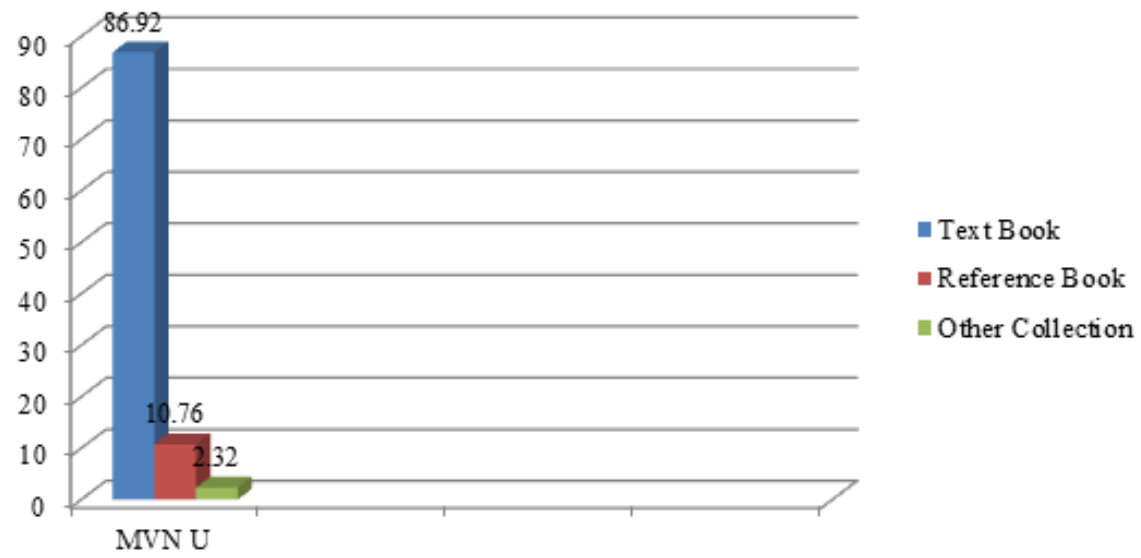

Table 2: Library staff situation

\begin{tabular}{|l|l|l|l|l|l|l|}
\hline Uni. Lib. & $\begin{array}{l}\text { Adm. Staff } \\
\mathbf{( \% )}\end{array}$ & $\begin{array}{l}\text { Tech. Staff } \\
(\boldsymbol{\%})\end{array}$ & $\begin{array}{l}\text { Clerical } \\
\text { Staff } \mathbf{( \% )}\end{array}$ & $\begin{array}{l}\text { Other } \\
(\boldsymbol{\%})\end{array}$ & Total & \\
\hline M V N University, Palwal, Haryana & $(3) 25.00$ & $(5) 41.67$ & $(1) 8.33$ & $(3) 25.00$ & 12 & $100 \%$ \\
\hline
\end{tabular}




\section{Diagram 2: Library staff situation in M V N university library}

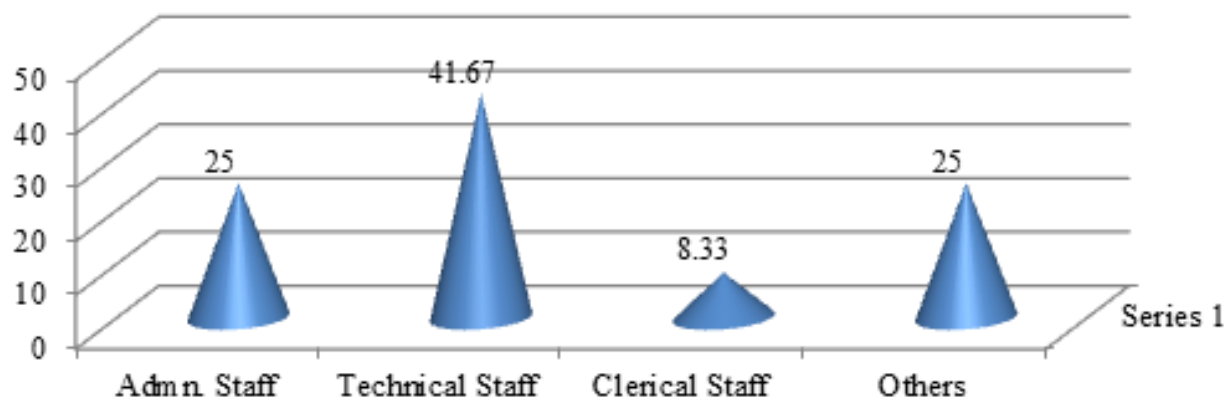

Table 3: Use of e-resources

\begin{tabular}{|l|l|l|}
\hline S. No. & \multicolumn{1}{|c|}{ Quarry } & Per. ratio \\
\hline 1 & Update information access & $45.00 \%$ \\
\hline 2 & Easiness in information access & $16.20 \%$ \\
\hline 3 & Information access speed & $25.7 \%$ \\
\hline 4 & Wider series of information & $13.10 \%$ \\
\hline & \multicolumn{2}{|c|}{} \\
\hline
\end{tabular}

Diagram 3: Use of e-resources

\section{Preference of electronic information resources}

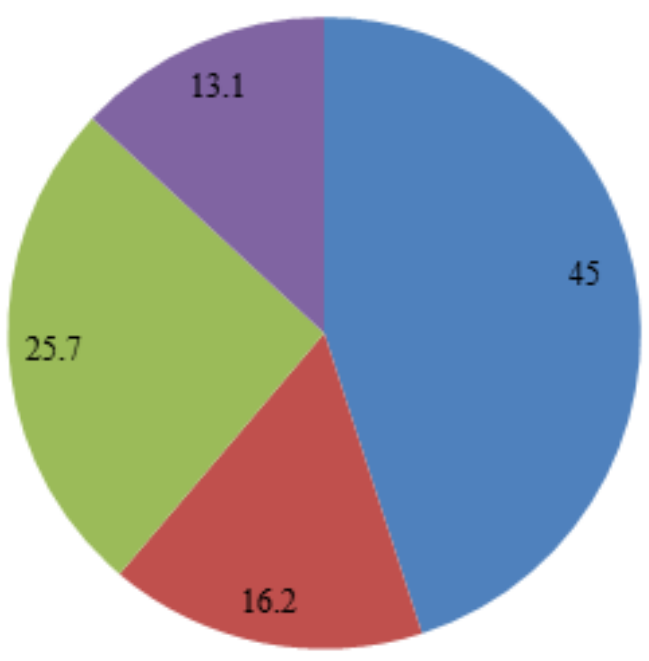

- Access to current up to date information

Easier access to information

- Faster access to information

n Access to wider range of information

Table 4: E-resources accessing barriers

\begin{tabular}{|l|c|c|c|}
\hline \multirow{2}{*}{ Barriers } & \multicolumn{2}{|c|}{ \% } & \multirow{2}{*}{ Total } \\
\cline { 2 - 3 } & Yes & No barriers & \\
\hline Infra-structure Lack of & $40 \%$ & $60 \%$ & $100 \%$ \\
\hline Un-organized Info. & $45 \%$ & $55 \%$ & $100 \%$ \\
\hline Difficulties in Screen Reading & $35 \%$ & $65 \%$ & $100 \%$ \\
\hline Lack of Training & $55 \%$ & $45 \%$ & $100 \%$ \\
\hline Print Resources Preference & $20 \%$ & $80 \%$ & $100 \%$ \\
\hline
\end{tabular}


Diagram 4: E-resources accessing barriers

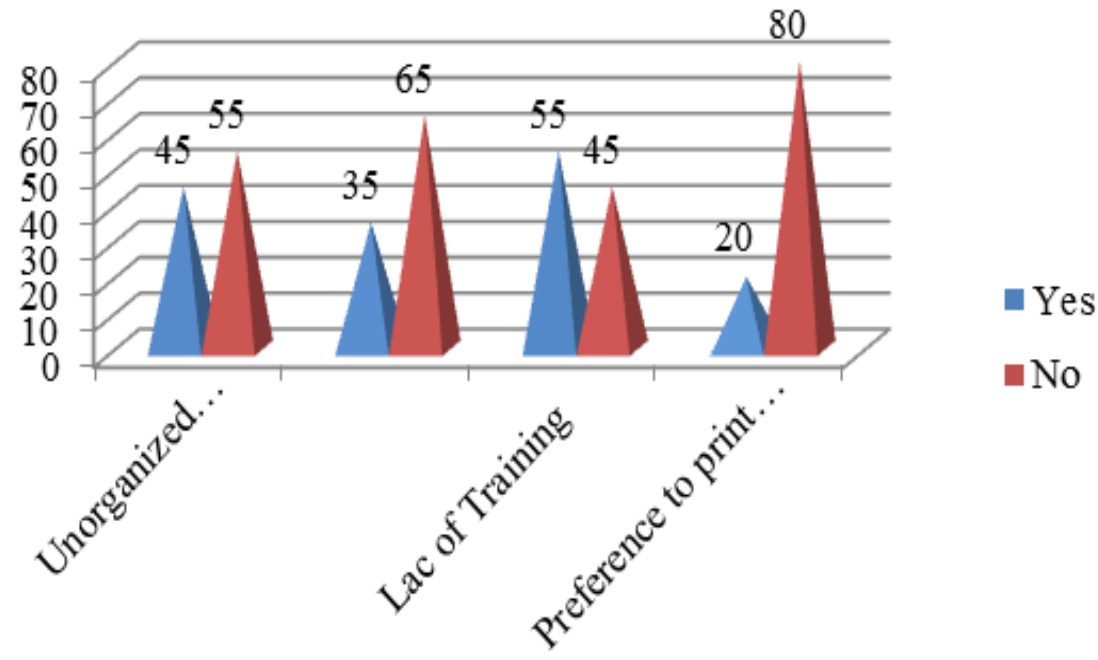

Table 5: In university library purpose of using e-resources

\begin{tabular}{|c|c|c|c|c|c|c|}
\hline $\begin{array}{c}\text { University } \\
\text { Library }\end{array}$ & $\begin{array}{c}\text { Res. } \\
\text { Purpose }\end{array}$ & $\begin{array}{c}\text { update } \\
\text { information }\end{array}$ & assignments & $\begin{array}{c}\text { cited } \\
\text { article }\end{array}$ & Other & Total \\
\hline MVNU & $35 \%$ & $25 \%$ & $15 \%$ & $22 \%$ & $3 \%$ & $100 \%$ \\
\hline
\end{tabular}

Diagram 5: University library purpose of using e-resources

\section{Purpose of using e-resources}

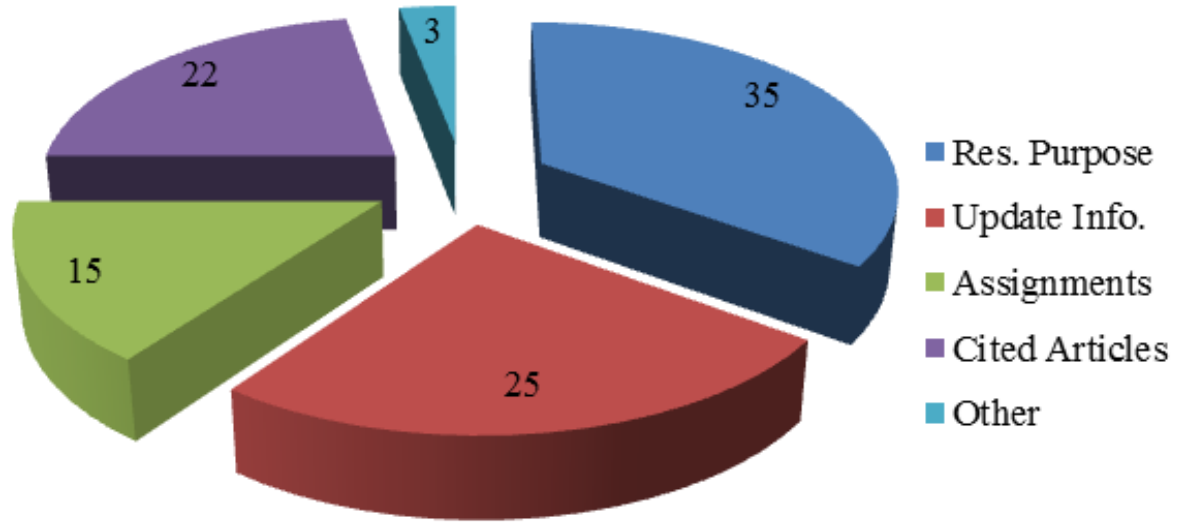

\section{Conclusion}

As outcome the existing case study finds that the use of electronic-resources is in demand. The collection of print and e-resources are sufficient and the management of this resource is well technical. The maximum users are used eresources for research purpose. Library staff is not found sufficient. However the services are in good condition in the library. Due the lack of staff members library staff feel burden and do not provide training properly. Hard reading materials are in good condition and university library purchased e-resources as their requirement. Users are finding satisfied from library services.

\section{References}

1. Devi, Suleta and Devi, Sangeeta. Management of e-resources in modern library information. An Outlook Inflibnet institutional repository, 2006; 360-364.

2. Doraswamy, M. Knowledge and use of digital library resources by engineering faculty members affiliated to Acharya Nagarjuna University, Peari, and A.P. Pearl: J Libr Inf Stud 2007;1(3):32-39.

3. Shelburne, Wendy Allen (). E-Book usage in an academic library: User attitudes and behaviors. Elsevier sci direct 2009;33(2-3):59-72. 
4. Sharma, Chetan . Use and impact of e-resources at Guru Govind Singh Indraprastha University (India): a case study. Electron J Acad Spec Libr 2009;10(1):10-13.

5. Arora, Tarun; Gurdev Singh . Use of e-resources in college libraries of Delhi. Libr Herald 2010;48(4):363-375.

6. Sathiyamurthi, M. G. and M. Arvinthan (2010). Access of eresources by B. Ed. Colleges in Cuddalore District, Tamil Nadu: a study. IJISS, 0973-8967, 4(1), 42-47.

7. Natarajan, K. Use and user perception of electronic resources in Annamalai University: A case study. Ann. Lib. Inf. Stud 2010;57(1): 59-64.

8. Sinha, K. Manoj (2011). Information and communication technology (ICT) awareness amongst university and college teachers of NE region of India: a survey. Libr Prog Int 2010;31(2): 217-234.

9. Nabi Hasan (2011). Turning the page: Issue, Challenges and future of e-books. NCILSCLDE, Vayu education; New Delhi. 978-93-80097-31-2, 33-43.

10. Adeniran, Pauline . User satisfaction with academic libraries services: Academic staff and students perspectives. Int J Libr Inf Sci 21412537, 2011;3(10);209-216.

11. Ruch Rani, et al (2011). E - Resources and e-learning in higher education and its effects. NCILSCLDE. Vayu Education; New Delhi. 978-93-80097-31-2, 58-60.
12. Sharma, Vipin; Dagar, Satish kumar (2011). E - Resources management. NCILSCLDE, Vayu education; New Delhi. 97893-80097-31-2, 407-11.

13. Shukla, Praveen; Mishra, Rajani (2011). Use of e-resources by research scholars of Institute of Technology, Banaras Hindu University, India. Res World J Arts, Sci Commerce. 22314172, 2011; 2(2):184-194.

14. Tyagi, Sunil (2011). Scientists' Perception of Use of Electronic Information Resources: A Case Study of Pharmacopoeia Laboratory for Indian Medicine (PLIM). Libr Philos Pract. 1522-0222.

15. Ray, Barnali (2011). E - Resources: its role and implications on libraries. NCILSCLDE, Vayu education; New Delhi. 97893-80097-31-2, 554-59.

16. Bhatia, Jaspal Kaur. (Use of electronic resources in degree college libraries in Chandigarh. DESIDOC J Libr Inf. Tech. 2011;31(6):480-484.

17. S. Dhanavandan; M. Tamizhchelvan. An evaluation of eresources in academic libraries in Tamil Nadu. J emerg trends comput inf serv. 2079-8407,2012: 3(3):421-426.

How to cite this article: Chand. S, Uses of information resources: An analytical study of library services of MNV university , Indian j Libr Sci inf techno. 2018;3(2):74-78 